If you would like more information on APSA's research grants or have suggestions for the committee, please contact Michael Brintnall at APSA. The 1994 competition will be announced in the December PS.

\section{Congressional Fellowship Program Announces 1993-94 Competition Winners}

\section{Political Scientists, Reporters Named APSA Congressional Fellows}

The American Political Science Association has announced the winners in the national competition for the 1993-94 Congressional Fellowship Program. Following a one-month orientation seminar, Fellows work full time for nine months as professional staff assistants to members of Congress or congressional committees.

The new Political Science and Journalism Congressional Fellows are:

Carol E. Buckland, News Writer, Cable News Network, Atlanta

Anne Marie Cammisa, Assistant Professor, Department of Political Science, University of New Hampshire

David Corvette, former General Assignment Reporter, The Atlanta Journal-Constitution

Timothy M. Johnson, News Director, Trend Broadcasting, Jamestown, NY

Barbara Joseph, Political and Federal Affairs Correspondent, Topeka Capital-Journal, Topeka, KS

Allen Kay, Congressional Issues Reporter, WPOP, Connecticut State Network

Sean Q. Kelly, Assistant Professor, Department of Political Science, East Carolina University

Ronald G. Shaiko, Assistant Professor, Department of Government, The American University

Christopher Weare, Lecturer, Graduate School of Public Policy, University of California, Berkeley

Daniel Wirls, Assistant Professor of

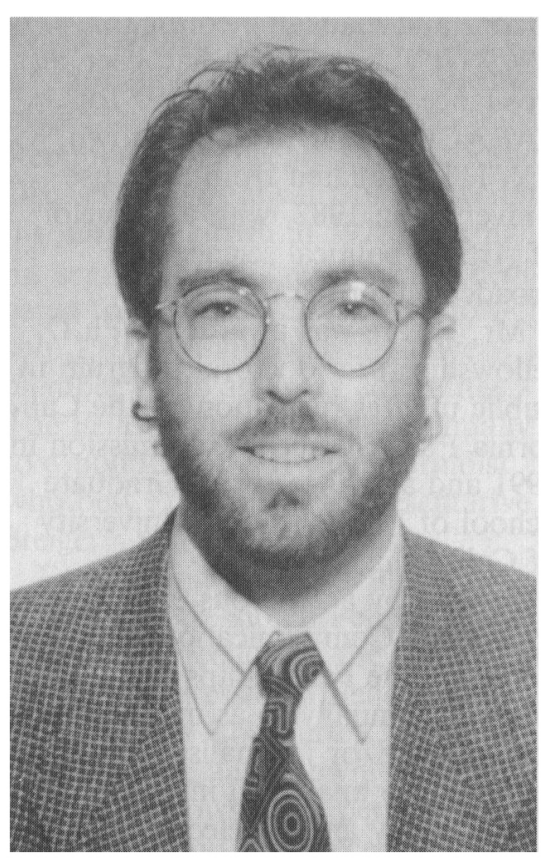

Sean Q. Kelly

Politics, University of Cálifornia, Santa Cruz

\section{Federal Executives Win Congressional Fellowships}

The Association also selected 19 federal executives as Congressional Fellows for the 1993-94 program and expects to name two more before September.

The recipients, advanced career civil servants, are scheduled to participate in the program from early November 1993 through mid-August 1994.

Of the 19 federal executives, to date, seven have been named Foreign Affairs Fellows and will take part in a special two-month seminar on Congress and foreign policy. The course is taught by Frederick Holborn at the Paul H. Nitze School of Advanced International Studies, The Johns Hopkins University, prior to the beginning of the general orientation. Foreign Affairs Fellows are federal executives who serve in foreign policy positions in their agencies.

The 19 federal executive winners, listed below, were selected in a government-wide competition on the basis of professional experience, career goals, and interest in national politics and the legislative process.

Eileen S. Braun, Senior Intelligence
Analyst, National Security Agency Colleen E. Bruton, Director, OSHA Technical Data Center, Department of Labor.

Nancy DeLew, Program Analyst, Office of Health Policy, Office of the Assistant Secretary for Planning and Evaluation, Department of Health and Human Services

Deborah K. Johnson, Security Officer, Central Intelligence Agency

Mark Kalber, Major, C-130 Program Manager, Department of the Air Force, National Guard Bureau

Maureen T. Koetz, Attorney-Adviser (General), Office of the General Counsel, Department of the Air Force

Maureen J. McBrien, Forest Planner, U.S. Forest Service, Department of Agriculture

Herbert H. Nelson, Head, Molecular Dynamics Section, Naval Research Laboratory, Department of the Navy

Stephen M. Oppermann, Supervisory Personnel Management Specialist, National Park Service, Department of the Interior

Joe H. Sanchez, Jr., Supervisory Communications Computer Systems Specialist, Air Force Intelligence Command, Department of the Air Force

Harriett A. Schneider, Senior Operational Staff Officer, National Security Agency

Paul J. Seligman, Section Chief and Supervisory Medical Officer, Surveillance Branch, Division of Surveillance, Hazard Evaluation and Field Studies, National Institute for Occupational Safety and Health, Department of Health and Human Services

\section{Foreign Affairs Fellows}

Lois A. Cecsarini, Foreign Service Officer, U.S. Department of State

David W. Davis, LTC, PoliticoMilitary Affairs Officer and Strategist, Office of the Deputy Chief of Staff for Operations and Plans, Department of the Army

Michael P. Fleming, Major, Inspector General Investigator, Department 
of the Army, National Guard Bureau

W. Robert Gerber, Intelligence Officer, Central Intelligence Agency

Ronald G. Houle, Major, Test Management Division, Operational Test and Evaluation Command, Department of the Army

Debra Lynn Shelton, Manager, System Acquisition Support, Directorate for Scientific and Technical Intelligence, Acquisition Support, Defense Intelligence Agency

Richard I. Stark, Jr., Major, Logistics Readiness Officer, Health Care Operations Directorate, Office of the Surgeon General, Department of the Army

\section{Political Scientists and Journalists Winners of Designated Congressional Fellowships}

Timothy Johnson and Christopher Weare Named APSA-MCI Communications Congressional Fellows

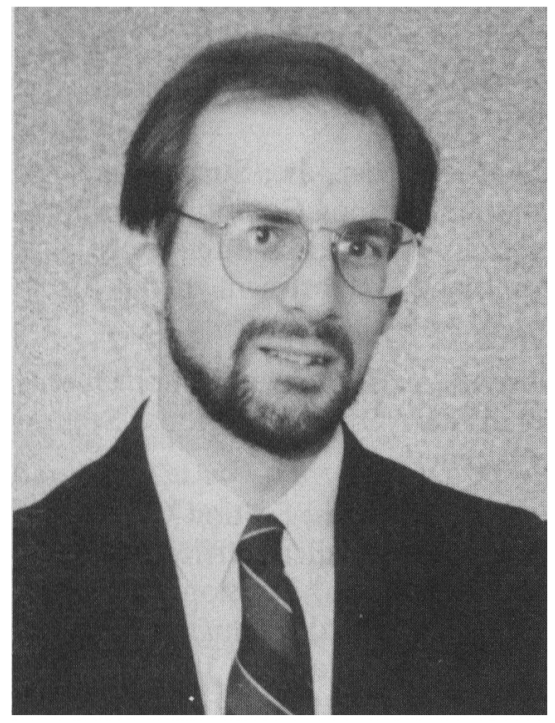

Timothy M. Johnson

Timothy M. Johnson, news director, Trend Broadcasting, Jamestown, NY; and Christopher Weare, Ph.D. candidate, Graduate School of Public Policy, University of California, Berkeley, have been named the 1993-94 APSA-MCI Communications Congressional Fellows.

Mr. Johnson has been with Trend Broadcasting since 1982. Before becoming news director for WKSNWHUG Newscenter he was founding anchor and managing editor for WKSN-TV, and earlier had been a free-lance television producer for PARAGON CABLE, Jamestown, NY. He graduated from Syracuse University in 1982, with a Bachelor of Arts in political science and broadcast journalism.

Mr. Weare was awarded a Ph.D. fellowship for a doctoral program in public utilities regulation by the California Public Utilities Commission in 1991 and also is lecturer, Graduate School of Public Policy, University of California, Berkeley.

Funded by a generous endowment from MCI Communications Corporation, the Fellowships are awarded annually to as many as two scholars and/or journalists who have exhibited an analytical interest in public policy and in telecommunications. In keeping with the Congressional Fellowship Program's goals, winners must be individuals who show promise of making a significant contribution to the public's understanding of the political process.

The first recipient of the APSAMCI Communications Congressional Fellowship was awarded to 1992-93 Congressional Fellow Shannon LeHere Fioravanti, former deputy bureau chief, Westinghouse Broadcasting, Washington, DC.

\section{Carol E. Buckland: Joan Shorenstein Barone Congressional Fellow}

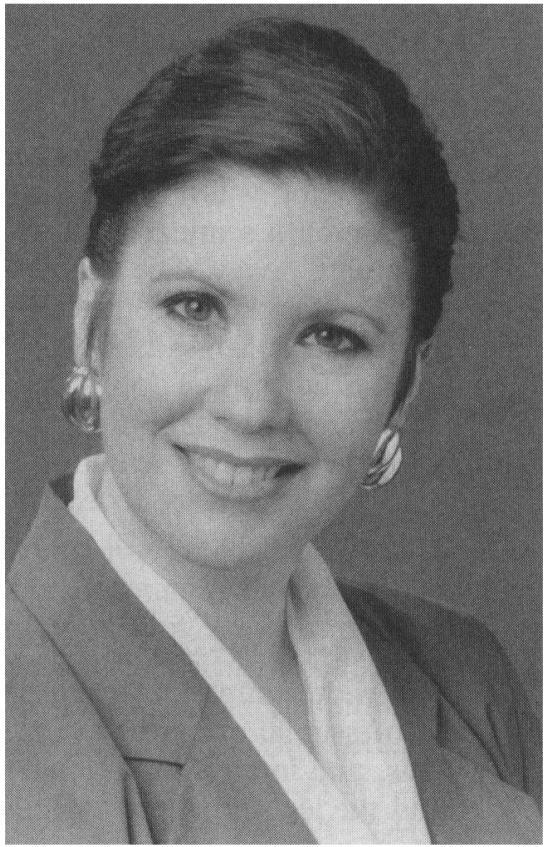

Carol E. Buckland
Carol E. Buckland, news writer, Cable News Network, is the recipient of the 1993-94 Joan Shorenstein Barone Congressional Fellowship, awarded by the Association each year to an outstanding broadcast journalist.

Ms. Buckland has been with CNN since 1981, where her duties included comprehensive coverage of the 1988 and 1992 presidential candidates, public policy issues, and campaign operations. From 1976 through May 1991 she was a reporter for The MacNeil/Lehrer Report. Ms. Buckland graduated summa cum laude from the University of Connecticut and received a Masters of International Affairs from Columbia University.

The Joan Shorenstein Barone Congressional Fellowship commemorates Joan Shorenstein Barone and the standards she set for accurate, thorough, and dignified reporting of current events, first as a researcher at the Washington Post and subsequently as a producer at CBS News.

Funding for the Joan Shorenstein Barone Congressional Fellowship is generously provided by her parents, Walter and Phyllis Shorenstein, and family.

\section{David Corvette: Poynter Fellow}

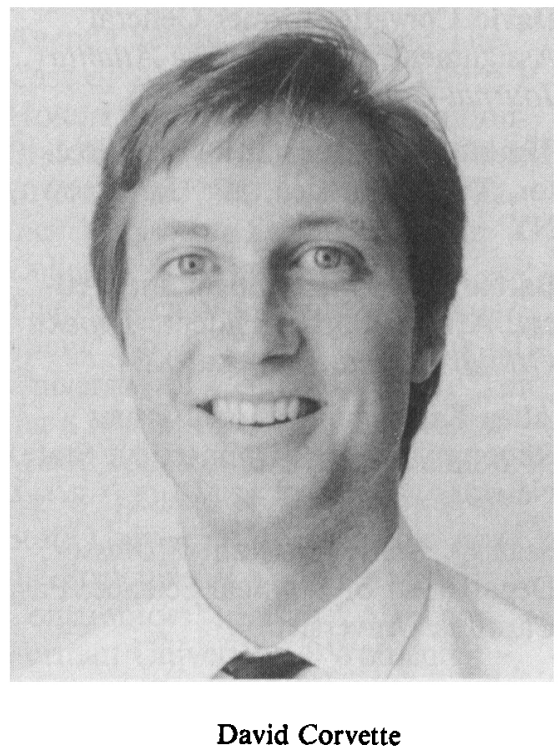

David Corvette, former general assignment reporter for The Atlanta Journal-Constitution, has been named the 1993-94 Poynter Fellow. 
The Fellowship is awarded to an outstanding print journalist.

Mr. Corvette had been with The Atlanta Journal-Constitution since 1982. Before becoming general assignment reporter, he had covered police, courts, and local government at the county and regional level. In 1982 he graduated magna cum laude from South Carolina College, University of South Carolina, with a Bachelor of Arts degree in journalism.

Funding for the 1993-94 Poynter Fellow is generously provided by Congressional Quarterly Inc., publishers of a family of resources that inform the public about Congress, national issues, and the American political process. Congressional Quarterly was founded in 1945 by Nelson Poynter.

Ronald G. Shaiko: William $A$. Steiger Congressional Fellow

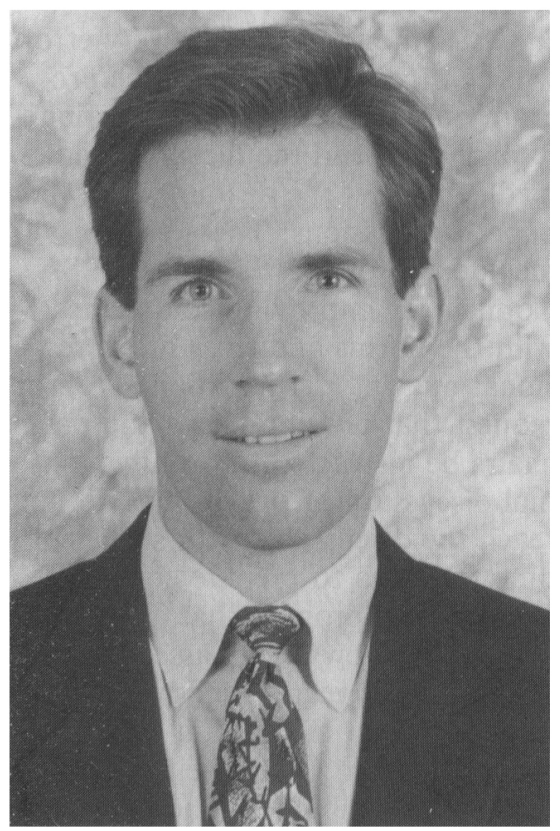

Ronald G. Shaiko

Ronald G. Shaiko, assistant professor, department of government, The American University, has been named the 1993-94 William A. Steiger Congressional Fellow.

Dr. Shaiko joined the faculty of The American University in 1990 and previously had been assistant professor, department of political science, at Virginia Polytechnic Institute and State University. He earned his Ph.D. in political science from
Syracuse University in 1989.

The William A. Steiger Congressional Fellowship honors the memory of the late William W. Steiger, a Republican who represented the Sixth District of Wisconsin from 1966 until his untimely death in 1978. During his service in Congress, he was dedicated to the Congressional Fellowship Program and was an active member of its advisory committee. The Fellowship is awarded annually to a political scientist or journalist who best exemplifies Representative Steiger's values and interests.

Fundraising for the William A. Steiger Congressional Fellowship is under the direction of the William A. Steiger Congressional Fellowship Development Committee, which seeks to raise an endowment to support the Fellowship in perpetuity. The Fellowship fund receives contributions annually from former Congressional Fellows and other friends of the Congressional Fellowship Program.

All designated Fellowships are awarded through rigorous national competition.

\section{Robert Wood Johnson Foundation Reauthorizes Congressional Fellowship Program Participation}

In April 1993, the Robert Wood Johnson Foundation's Board of Directors reauthorized funding of the Robert Wood Johnson Health Policy Congressional Fellowships for another five years, beginning with the 1993-94 year. APSA will continue to include the health policy professionals in the Congressional Fellowship Program, along with political scientists and journalists, federal executives, international fellows, and others.

\section{Ralph Bunche Summer Institute}

Ten outstanding juniors who have demonstrated potential in the field of political science participated in the eighth annual APSA Summer Institute in Political Science for African American Students. The Summer Institute is in honor of Ralph Bunche, winner of the Nobel Peace Prize and former APSA President.
The Institute held June 7-July 2 in Atlanta, Georgia, was conducted by a consortium consisting of Spelman College, Morehouse College, Georgia State University, Emory University, and Clark Atlanta University. Dr. Jeanne T. Meadows of Spelman College was the director of the 1993 Institute; the 1992 Institute was directed by Dr. Lois T. Moreland. Professor Tobe Johnson of Morehouse College, Dr. C. T. Cummings and Professor William Thomas of Georgia State University, Professor Alan Abramowitz and Dr. Eleanor Main of Emory University, and Professor William Boone of Clark Atlanta University were coordinators for their respective campuses.

Summer Institute Participants

Cheryl D. Anderson, Spelman College

Satyra L. Austin, Baylor University

Derwyn D. Bunton, San Diego State University

Lynda Caine-Barrett, Texas Southern University

Renita M. Edwards, University of Louisville

Kendra A. King, Colby College

Natasha C. Marcus, Emory

University

Kimaka Nichols, Winthrop

University

Kenneth H. Perrin, Queens College

Terrence L. Walker, University of Maryland

\section{Annual Meeting Paper and Preprint Archive on Internet}

The APSA and other associations are making judicial process and constitutional law papers available on the Internet beginning September 15, 1993. The first set of papers will be from the 1993 APSA meetings; papers from other meetings will follow. The papers will be available for a period of two years. At the beginning, two separate procedures will allow users to access them.

The first is ftp (file protocol trans- 